\title{
Analisis Faktor-Faktor yang Mempengaruhi CSR Disclosure Pada Perusahaan Manufaktur yang Terdaftar di BEI Periode 2016-2018
}

\author{
Dara Nida Utamie 1 \\ Fakultas Ekonomi dan Bisnis \\ Universitas Mataram, Indonesia \\ Email: dnida45@gmail.com
}

\author{
Akram² \\ Fakultas Ekonomi dan Bisnis \\ Universitas Mataram, Indonesia
}

\section{Nyoman Nugraha Ardana Putra ${ }^{3}$ \\ Fakultas Ekonomi dan Bisnis \\ Universitas Mataram, Indonesia}

\begin{abstract}
ABSTRAK
Penelitian ini bertujuan untuk menganalisis komite audit, profitabilitas, ukuran perusahaan dan leverage terhadap CSR Disclosure. Populasi penelitian adalah perusahaan manufaktur yang terdaftar di BEI tahun 2016-2018 yang mengungkapkan laporan tahunan dan laporan CSR. Sampel ditentukan dengan purposive sampling dan diperoleh 342 amatan. Data penelitian dianalisis dengan menggunakan metode regresi linier berganda. Temuan penelitian menunjukan bahwa komite audit, profitabilitas dan ukuran perusahaan berpengaruh positif signifikan terhadap CSR Disclosure, sedangkan leverage berpengaruh negatif tidak signifikan terhadap CSR Disclosure. Implikasi dari penelitian ini bahwa CSR Disclosure perlu di jadikan sebagai salahsatu alat strategi jangka panjang perusahaan yang pada nantinya dapat memberikan manfaat kepada para stakeholders sehingga dapat menjadi pertimbangan bagi para investor dalam pengambilan keputusan.
\end{abstract}

Kata Kunci: Komite Audit; Profitabilitas; Ukuran Perusahaan; Leverage; CSR Disclosure.

\section{Analysis of Factors Affecting CSR Dislosure in Registered Manufacturing Companieson IDX for the period of 2016- 2018}

\section{ABSTRACT}

The research aims to analyze the Audit Committee, Profitability, Company Size and Leverage on CSR Disclosure. The study population is manufacturing companies listed on the Stock Exchange in 2016-2018 which reveal annual reports and CSR reports. The sample was determined by purposive sampling and 342 observations were obtained. Research data were analyzed using multiple linear regression methods. The research findings show that the Audit Committee, Profitability and Company Size have a positive and significant effect on Corporate Social Responsibility Disclosure, while leverage has a negative and not significant effect on CSR. The implication of this research is that CSR needs to be made as one of the company's long-term strategic tools which in turn can benefit stakeholders so that it can be considered by investors in making decisions.

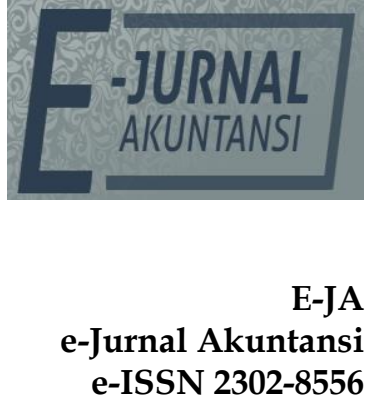

Vol. 30 No. 1

Denpasar, Januari 2020 Hal. 265-276

Artikel Masuk: 19 November 2019

Tanggal Diterima: 10 Januari 2020

Keywords: Audit Committee, Profitability, Company Size, Leverage, CSR Disclosure. 


\section{PENDAHULUAN}

Perkembangan dunia bisnis di Indonesia dari tahun ke tahun semakin pesat. Perusahaan dihadapkan pada lingkungan bisnis yang bergerak sangat dinamis. Perusahaan agar mampu bertahan dalam kondisi tersebut cara yang dilakukan salah satunya dengan berkontribusi terhadap lingkungan dengan melakukan kegiatan yang dapat memberikan manfaat bukan hanya kepada Perusahaan namun kepada penduduk dan lingkungan sekitar. Bagaimanapun Perusahaan juga harus menjaga hubungan yang baik dengan para stakeholders (Irfandi, 2014). Adanya keterkaitan erat antara Perusahaan dengan masayarakat sekitar dan lingkungan, dimana dalam menjalankan aktivitasnya saling memberi dan membutuhkan. Cara yang dilakukan dengan melakukan aktivitas CSR (Respati \& Hadiprajitno, 2015)Pada jangka panjang Perusahaan akan memperoleh laba dengan memperhatikan laporan keberlanjutan (Ilene, 2016).

Beberapa regulasi yang mengatur tentang pelaksanaan CSR di Indonesia antara lain Undang-undang Nomor 40 tahun 2007 tentang Perseroan Terbatas yang mengatakan bahwa Perusahaan yang menjalankan kegiatan usahanya berkaitan langsung dengan sumber daya alam diwajibkan dalam melaksanakan tanggung jawab sosial lingkungannya. Selain itu, diterbitkannya lagi Peraturan Pemerintah Nomor 47 Tahun 2012 yang dapat melengkapi Undang-Undang tersebut.

Kondisi persaingan di Bursa Efek Indonesia yang berkembang pesat saat ini membuat banyak investor antusias untuk dapat menginvestasikan sebagian modalnya kepasar modal Indonesia. Melihat Perusahaan Manufaktur memiliki sumbangsih yang cukup besar dalam pencemaran lingkugan saat proses produksinya mengharuskan Perusahaan dalam mengelola dan mengolah hasil limbah tersebut .Selain itu juga Perusahaan melibatkan banyak tenaga kerja yang pada nantinya Perusahaan juga memiliki tanggungjawab terhadap keselamatan para pekerja.Perusahaan dalam menyalurkan hasil produksinya yaitu menjual produk kepada konsumen menuntut Perusahaan juga harus memiliki tanggungjawab atas keamanan produk yang dihasilkan.

Organisasi berperan sebagai agen yang menggunakan sumber daya yang ada dan bertanggung jawab atas penggunaannya secara berkelanjutan (Da Silveira \& Petrini, 2018)Terkait dengan hal tersebut berbagai program dalam pengimplementasian CSR telah dilakukan oleh perusahaan. Adapun kegiatan program-program tersebut diantaranya berupa bantuan beasiswa, pembinaan, permodalan dan pelatihan untuk usaha kecil menengah, penyaluran kredit modal kerja untuk UMKM, pemberian makanan tambahan untuk anak guna menghindari gizi buruk, penyuluhan mengenai penanggulangan bencana untuk karang taruna dan lain sebagainya.

Corporate Social Responsibility Disclosure (CSRD) dipengaruhi oleh beberapa faktor diantaranya yaitu komite audit. Komite audit merupakan komite yang dibentuk untuk membantu dewan komisaris dalam menjalankan fungsinya dalam hal pengawasan. Selain itu keberadaankomite audit dapat juga mendorong pihak manajemen dalam mengungkapkan aktivitas sosial dan lingkungannya. Hasil penelitianyang dilakukan (Nyoman et al., 2018),(Fadhilla, 2017),(Erwanti, 2017) dan (Sayidah, 2017) menemukan bahwa komite audit 
berpengaruh positif terhadap CSRD. Berbeda halnya dengan temuan (Hang \& Ngoc, 2018) tidak menemukan adanya pengaruh.

Profitabilitas diperkirakan akan mempengaruhi CSRD.Pihak investor akan selalu memperhatikan rasio profitabilitas sebagai bahan pertimbangan nantinya jika ingin menginvestasikan dana yang dimiliki. Karena dalam jangka panjang para pemegang saham akan melihat bagaimana laba yang bakal diterima kedepannya dalam bentuk dividen dengan memanfaatkan asset yang dimiliki. Hasil penelitian yang dilakukan oleh (Oktavianawati \& Sri, 2018), (Abdullahi \& Ali, 2018), (Rohmah, 2015), (Laksmitaningrum \& Purwanto, 2013), (Badjuri, 2011), (Roitto, 2013) dan (Lucyanda \& Siagian, 2012) menunjukkan bahwa profitabilitas berpengaruh terhadap CSRD, hal inidisebabkan karena perusahan dengan laba tinggi cenderung akan melaporkan aktivitas social dan lingkungannya. Berbeda halnya dengan temuan (Triyono \& Achyani, 2016) dan (Respati \& Hadiprajitno, 2015) bahwa profitabilitas tidak berpengaruh terhadap CSRD.

Selain itu, Ukuran perusahaan juga dapat diperkirakan mempengaruhi CSRD. Ukuran perusahaan biasanya dinyatakan dengan total aktiva. Perusahaan yang besar biasanya mempunyai informasi yang lebih banyak untuk memenuhi kebutuhan para stakeholders. Hasil penelitian yang dilakukan oleh (Abdullahi \& Ali, 2018), (Cahyaningtyas, 2018), (Oktavianawati \& Sri, 2018), (Waluyo, 2017), (Ilene, 2016), (Dijk, 2015), (Trencansky et al., 2014), (Lucyanda \& Siagian, 2012))menemukan bahwa ukuranperusahaan berpengaruh terhadap CSRD. Adanya pengungkapan sosial menyebabkan pengurangan biaya politis bagi perusahaan. Jika perusahaan senantiasa aktif dalam pembangunan berkelanjutan maka dalam jangka waktu panjang akan terhindar dari biaya yang besar akibat tuntutan masyarakat.

Faktor lain yang dapat mempengaruhi CSRD yaitu leverage. Leverage adalah rasio total utang terhadap total ekuitas. Perusahaan dalam menjalankan usahanya memperoleh dana dari pihak eksternal, salahsatunya yaitu dengan utang. Utang digunakan oleh perusahaan dalam ekspansi bisnisnya, karena dana internal biasanya tidak mencukupi. Perusahaan yang memiliki tingkat leverage tinggi akan lebih banyak mengungkapkan informasi sosial dan lingkungan. (Cahyaningtyas, 2018), Ratna \& Mardi (2018), Yusuf (2017) dan Badjuri (2011) menemukan Leverage berpengaruh terhadap CSRD.

Adanya ketidakkonsistenan hasil penelitian, menunjukkan bahwa isu tentang CSR pada saat ini masih menjadi topic yang sangat penting dan memiliki kemungkinan untuk berkembang kedepan. Berdasarkan fenomena yang ada memotivasi peneliti untung membahas isu CSR sebagai focus dalam penelitian yang pada nantinya diharapkan dapat memberikan kontribusi yang positif terhadap kelangsungan Perusahaan. Mengingat Perusahaan memiliki tanggungjawab moral yang besar yang pada nantinya dapat menciptakan pembangunan secara berkelanjutan baik bagi Perusahaan ataupun lingkungan sekitar.

Berdasarkan fenomena diatas, maka ditentukan rumusan masalah pada penelitian ini yaitu apakah apakah Komite audit,profitabilitas, ukuran perusahaan dan leverage berpengaruh terhadap Corporate Social Responsibility Disclosure perusahaan. 
Adapun grand theory yang digunakan pada penelitian ini yaitu, stakeholders theory dan agency theory. Stakeholders theory merupakan teori yang berkaitan dengan pemenuhan kepentingan para stakeholders dengan kata lain merupakan kumpulan kebijakan, nilai-nilai, pemenuhan hokum, dan penghargaan kepada masyarakat dan lingkungan yang berkomitmen mendukung pembangunan berkelanjutan (Freeman, 1981). Para pemakai laporan keuangan tentunya penting untuk melihat kinerja perusahaan bukan hanya dari segi kinerja keuangan saja, namun diimbangi dengan kinerja lingkungan yang tidak kalah penting yang merupakan salah satu pertimbangan kedepan dalam menjalankan sebuah bisnis (Basuki \& Patrioty, 2017). Melalui CSR diharapkan dapat mengurangi asimetri informasi yang merupakan agency problem dalam kaitannya dengan agent dan principal, karena pada agency theory, pihak manajemen memilik informasi yang lengkap dibandingkan pemilik perusahaan sehingga pihak manajemen akan memilih informasi yang akan diungkapkan.

CSR merupakan upaya yang dilakukan perusahaan dalam menjaga kelestarian lingkungan dan memperbaiki kondisi sosial masyarakat sekitarnya. Perusahaan menyadari bahwa keberhasilannya dalam mencapai tujuan juga dipengaruhi oleh komunitas atau masyarakat di sekitar perusahaan, selain dari faktor internal saja, karena program CSR ini merupakan keharusan yang harus dilakukan seiring dengan munculnya berbagai tuntutan dari sekitarnya (Mardikanto, 2014:199). Ini berarti bahwa, telah terjadi pergeseran dalam hubungan antara perusahaan atau perusahaan dengan masyarakat atau komunitas di sekitarnya. Salah satu upaya yang dapat diselesaikan oleh perusahaan untuk menjalin hubungan kemitraan yang baik dengan masyarakat di sekitar perusahaan adalah melalui program hubungan masyarakat yang merupakan metode berinteraksi dengan masyarakat yang saling terkait dengan operasi organisasi, sehingga program CSR akan ada banyak manfaat bagi perusahaan dan masyarakat (Mardikanto, 2014:199).

CSR merupakan cara yang digunakan dalam berkomunikasi dengan para stakeholder baik internal maupun eksternal. Adanya CSR dapat mendukung dalam pembangunan berkelanjutan, dimana Perusahaan dituntut bukan hanya focus terhadap profit tetapi juga harus memperhatikan dampak yang ditimbulkan dari proses produksi yang bisa saja mencemari lingkungan sekitar dalam jangka pendek maupun jangka panjang (Respati \& Hadiprajitno, 2015).

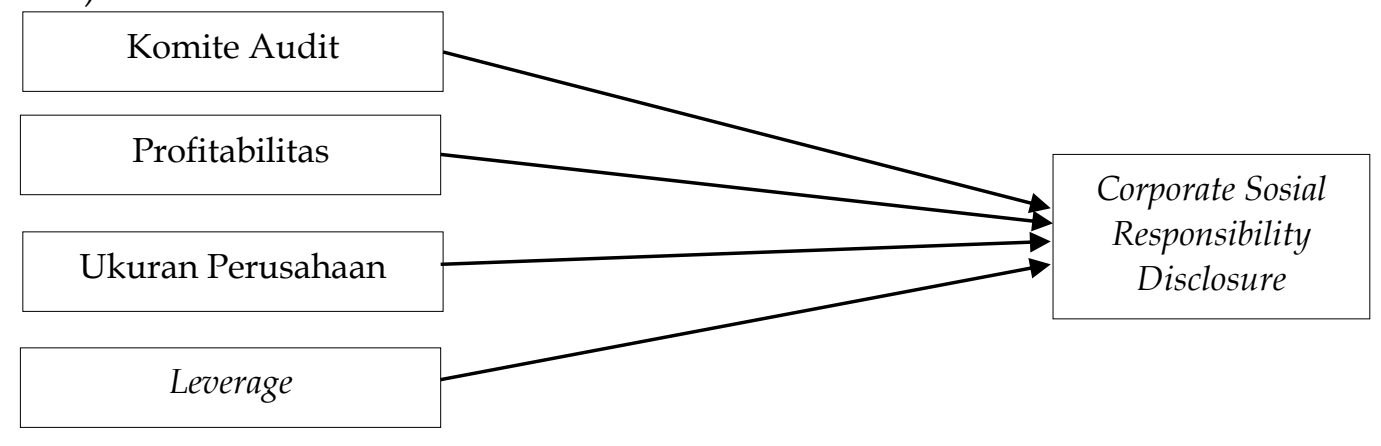

Gambar 1. Model Penelitian

Sumber: Data Penelitian, 2019 
Komite audit dibentuk untuk membantu dewan komisaris dalam menjalankan fungsinya. Semakin banyak komite auditakan memotivasi pihak manajemen dalam meningkatkan kinerja sosialnya. Karena salah satu tugas dari komite audit adalah memastikan perusahaan telah menjalankan usahanya sesuai dengan aturan atau undang-undang yang berlaku termasuk dalam kepatuhan mengungkapkan aktivitas sosial dan lingkungannya. Berdasarkan agency theory bahwa keberadaan komite audit dapat meminimalisir adanya konflik kepentigan antara manajemen dan pemilik perusahaan. Temuan dari (Nyoman et al., 2018), (Fadhilla, 2017), (Erwanti, 2017) dan (Sayidah, 2017)) menemukan bahwa komite audit berpengaruh positif terhadap CSRD.

$\mathrm{H}_{1}$ : Komite Audit Berpengaruh Positif terhadap CSRD.

Profitabilitas merupakan kemampuan perusahaan dalam menghasilkan laba dengan memanfaatkan asset yang dimiliki. Perusahaan yang memiliki tingkat profitabilitas tinggi akan cenderung lebih banyak mengungkapkan kinerja social dan lingkungannya sebagai alat komunikasi dengan para pemangku kepentingan, sehingga perusahaan sadar bahwa dalam beroperasi tidak hanya focus terhadap laba semata. Berdasarkan stakeholders theory bahwa perusahaan yang memiliki tingkat profitabilitas akan memenuhi kebutuhan para stakeholdersnya. Salahsatu bentuk nya dengan membagikan dividen dari sebagian laba yang dihasilkan, sehingga terlihat bahwa perusahaan merangkul kepentingan para stakeholder.Temuan dari (Oktavianawati \& Sri, 2018),(Abdullahi \& Ali, 2018), (Rohmah, 2015), (Laksmitaningrum \& Purwanto, 2013), (Badjuri, 2011),(Roitto, 2013) dan (Lucyanda \& Siagian, 2012) menunjukkan bahwa profitabilitas berpengaruh terhadap CSRD.

$\mathrm{H}_{2}$ : Profitabilitas berpengaruh Positif terhadap CSRD

Ukuran perusahaan adalah menggambarkan besar atau kecilnya suatu perusahaan yang bisa dilihat dari total aktiva.Perusahaan yang besar biasanya memiliki banyak pemangku kepentingan sehingga lebih disoroti dari perusahaan yang berukuran kecil. Berdasarkan agency theory bahwa perusahaan besar memiliki biaya keagenan yang besar pula, sehingga perusahaan akan lebih banyak mengungkapkan aktivitas social dan lingkungannya yang pada nantinya akan berpengaruh terhadap keberlanjutan Perusahaan kedepannya. Temuan dari (Abdullahi \& Ali, 2018), (Cahyaningtyas, 2018), (Oktavianawati \& Sri, 2018), (Waluyo, 2017), (Ilene, 2016), Djik (2015), (Trencansky et al., 2014),(Lucyanda \& Siagian, 2012) menunjukkan bahwa ukuran perusahaan berpengaruh terhadap CSRD.

$\mathrm{H}_{3}$ : Ukuran Perusahaanberpengaruh Positif terhadap CSRD

Leverage adalah rasio total utang terhadap total ekuitas. Rasio ini menggambarkan struktur modal perusahaan. Perusahaan dengan tingkat leverage yang tinggi akan cenderung mengungkapkan aktivitas social dan lingkungannya. Hal ini disebabkan karena Perusahaan akan menjadikan utang tersebut sebagai control dalam menjalankan kegiatan usahanya.Temuan dari (Cahyaningtyas, 2018), (Widyadmono, 2014), (Yusuf, 2017) dan (Badjuri, 2011)menunjukkan bahwa leverage berpengaruh terhadap CSRD.

$\mathrm{H}_{4}$ : leverage berpengaruh positif terhadap CSRD 


\section{METODE PENELITIAN}

Penelitianini dilakukan pada Bursa Efek Indonesia. Populasi dalam penelitian ini adalah seluruh Perusahaan Manufaktur yang terdaftar di Bursa Efek Indonesia (BEI) tahun 2016-2018.Populasi yang digunakan 167 perusahaan.

Sampel dalam penelitian ini adalah Perusahaan manufaktur yang terdaftar di Bursa Efek Indonesia (BEI) tahun 2016-2018.Jumlah sampelpenelitian ini sebanyak 114 Perusahaan.Teknik sampling yang digunakan dalam pengambilan sampel adalah purposive sampling.

\section{Tabel 1. Perhitungan Sampel}

\begin{tabular}{lll}
\hline No & Kriteria Pemilihan Sampel & $\begin{array}{l}\text { Jumlah } \\
\text { Perusahaan }\end{array}$ \\
\hline 1 & $\begin{array}{l}\text { Perusahaan yang termasuk dalam kategori perusahaan } \\
\text { manufaktur dan terdaftar di Bursa Efek Indonesia per } 31\end{array}$ & 167 \\
& $\begin{array}{l}\text { Desember 2016-2018 } \\
2\end{array}$ & $\begin{array}{l}\text { Perusahaan yang tidak menyajikan data secara lengkap per 31 } \\
\text { Desember 2016-2018 }\end{array}$ \\
3 & $\begin{array}{l}\text { Perusahaan yang tidak menyajikan pengungkapan CSR dalam } \\
\text { laporan tahunannya per 31 Desember 2016-2018 }\end{array}$ & $(19)$ \\
Perusahaan yang memenuhi kriteria sampel & 114 \\
Jumlah sampel (114 $\times 3)$ & 342 \\
\hline
\end{tabular}

Sumber : Data Penelitian, 2019

Komite audit merupakan komite yang dibentuk oleh Dewan Komisaris yang bekerja sama dalam melaksanakan tugas dan fungsi Dewan Komisaris. Komite audit diproksikan dengan menjumlahkan anggota komite audit pada suatu perusahaan pada laporan tahunan.

Profitabilitas merupakan rasio yang menunjukkan hasil atas jumlah aktiva yang digunakan perusahaan. Profitabilitas dalam penelitianini diukur dengan menggunakan Return on asset dengan rumus seperti berikut (Respati \& Hadiprajitno, 2015):

$\mathrm{ROA}=\frac{\text { Laba BersihSetelah Pajak }}{\text { Total Asset }} \times 100 \%$

Ukuran perusahaan merupakan skalaperusahaan yang dilihat dari total aktiva perusahaan pada akhir tahun. Proksi yang digunakan untuk mengukur ukuran perusahaan yaitu log natural total aset. Ukuran perusahaan diukur dengan rumus sebagai berikut (Yusuf, 2017):

Ukuran perusahaan $=\mathrm{Ln}$ (total aset)

Leverage merupakan proporsi utang terhadap modal.Leverage diukur dengan menggunakan rumus sebagai berikut (Respati \& Hadiprajitno, 2015) :

DER $=\frac{\text { Total hutang }}{\text { Total modal }}$

Pengukuran tingkat pengungkapan CSR pada penelitian ini menggunakan indikator berdasarkan GRI G4, dimana terdapat 91 itempengungkapan. Pengungkapan CSR diukur dengan menggunakan rumus sebagai berikut (Yusuf, 2017): 
$C S R I j=\frac{\text { Jumlahitem CSR yangdiungkap }}{91}$

Alat analisis yang digunakan dalam penelitian ini adalah menggunakan analisis regresi linier berganda yaitu untuk mengukur seberapa besar hubungan variabel independen dan variabel dependen sehingga dapat membedakan kedua variabel dalam penelitian (Ghozali, 2011). Adapun persamaan sebagai berikut :

$Y=a+B_{1} X_{1}+B_{2} X_{2}+B_{3} X_{3}+B_{4} X_{4}+e$

Keterangan :

Y :Corporate Social Responsibility Disclosure

a : Konstanta

$\beta_{1}-\beta_{4}$ : Koefisien Regresi

$\mathrm{X}_{1}$ : Komite Audit

$\mathrm{X}_{2}$ : Profitabilitas

$\mathrm{X}_{3}$ :Ukuran Perusahaan

$\mathrm{X}_{4}$ :Leverage

e :error

\section{HASIL DAN PEMBAHASAN}

Berdasarkan table 2 menunjukkan bahwa diperoleh hasil uji normalitas Kolmogorov-smirnov dengan nilai sig.(2-tailed) sebesar 0,076 > 0,05. Dari hasil tersebut residual pada model regresi berdistribusi secara normal.

Tabel 2. Hasil Uji Normalitas

\begin{tabular}{ll}
\hline & $\begin{array}{l}\text { Unstandardized } \\
\text { Residual }\end{array}$ \\
\hline $\mathrm{N}$ & 342 \\
Kolmogorov. Smirnov Z & 1.279 \\
Asymp.Sig. (2- tailed) & .076
\end{tabular}

Sumber : Data Penelitian, 2019

Berdasarkan table 3 menunjukkan bahwa diperoleh hasil uji normalitas Kolmogorov-smirnov dengan nilai sig.(2-tailed) sebesar 0,076 > 0,05. Dari hasil tersebut residual pada model regresi berdistribusi secara normal.

Tabel 3. Hasil Uji Autokorelasi

\begin{tabular}{|c|c|c|}
\hline Model & $\begin{array}{l}\text { Adjusted R } \\
\text { Square }\end{array}$ & Durbin-Watson \\
\hline 1 & .367 & 1.869 \\
\hline \multicolumn{3}{|c|}{$\begin{array}{l}\text { Sumber : Data Penelitian, } 2019 \\
\quad \text { Berdasarkan table } 4 \text {. Menunjukkan bahwa diperoleh nilai durbin Wats } \\
\text { untuk persamaan regresi yaitu 1,869. Nilai du 1,83392 dengan taraf signifikar } \\
\%, \mathrm{n}=342, \mathrm{k}=4 \text {. Oleh karena itu, nilai dw berada diantara 1,83392 (nilai du) d } \\
2,16608 \text { (4-du) yang artinya hal tersebut tidak terjadi problem autokorelasi. }\end{array}$} \\
\hline
\end{tabular}


Tabel 4. Hasil Uji Heterokedastisitas

\begin{tabular}{clll}
\hline & \multicolumn{3}{c}{$\begin{array}{c}\text { Unstandardized } \\
\text { Coefficients }\end{array}$} \\
\cline { 2 - 3 } Model & $\mathrm{B}$ & $\mathrm{t}$ & $\mathrm{sig}$ \\
\hline Komite Audit & .350 & 1.629 & .104 \\
Profitabilitas & -.007 & -1.597 & .111 \\
UkuranPerusahaan & .045 & .611 & .541 \\
Leverage & -.004 & -.569 & .570 \\
\hline
\end{tabular}

Sumber : Data Penelitian, 2019

Berdasarkan table 5. Menunjukkan bahwa komite audit mempunyai nilai signifikan 0,391 >0,05, profitabilitas mempunyai nilai signifikan 0,104 >0,05, ukuran perusahaan mempunyai nilai signifikan 0,541>0,05, leverage mempunai nilai signifikan 0,570>0,05. Dari hasil tersebut dapat disimpulkan bahwa modelregresi pada penelitian ini bebas dari problem heterokedastisits.

Tabel 5. Hasil Uji Multikolinearitas

\begin{tabular}{lll}
\hline & \multicolumn{2}{c}{ Collinearity Statistics } \\
\cline { 2 - 3 } Model & Tolerance & VIF \\
\hline Komite Audit & .852 & 1.174 \\
Profitabilitas & .947 & 1.056 \\
Ukuran Perusahaan & .849 & 1.178 \\
Leverage & .954 & 1.048 \\
\hline
\end{tabular}

Sumber : Data Penelitian, 2019

Berdasarkan tabel 6 menunjukkan bahwa Komite Audit diperoleh nilai tolerance $0,852>0,05$ dan VIF 1,174< 10,00, profitabilitas dengan nilai tolerance sebesar $0,947>0,05$ dan VIF 1,056 $<10,00$, ukuran perusahaan dengan nilai tolerance sebesar $0,849>0,05$ dan VIF 1,178 $<10,00$, Leverage memiliki tolerance sebesar 0,954 $>0,05$ dan VIF 1,048 < 10,00. Berdasarkan tolerance dan VIF dari semua variabel tersebut dapat disimpulkan bahwa modelregresi telah bebas dari problem multikolinearitas.

Tabel 6. Hasil Uji Statistik F

\begin{tabular}{llll}
\hline Model & & F & Sig. \\
\hline 1 & $\begin{array}{l}\text { Regression } \\
\text { Residual }\end{array}$ & 9.281 & .000 \\
\hline
\end{tabular}

Sumber : Data Penelitian, 2019

Berdasarkan tabel 7 menunjukkan bahwa modelnya fit dengan data diperoleh nilai $\mathrm{F}$ hitung sebesar $9.281>2.398134 \quad(\mathrm{~F}$ tabel) dengan nilai signifikan sebesar 0,000<0,05 artinya terdapat pengaruh variable bebas terhadap variable terikat secara simultan. Nilai signifikan $<0,05$ dapat disimpulkan bahwa hipotesis diterima yang artinya terdapat pengaruh positif signifikan antara variable komite audit, profitabilitas, ukuran perusahaan dan leverage terhadap variable CSRD yang artinya variable dependen mampu menjelaskan atau memprediksi variasi dari CSRD. 
Tabel 7. Hasil Uji Statistik $\mathbf{t}$

\begin{tabular}{lcccc}
\hline & $\begin{array}{c}\text { Unstandardized } \\
\text { Coefficients }\end{array}$ & $\mathrm{t}$ & Sig. & Hasil Uji \\
\cline { 2 - 3 } Model & $\mathrm{B}$ & & & Hipotesis \\
\hline Komite Audit & .189 & 2.130 & .034 & Diterima \\
Ukuran Perusahaan & .027 & 5.044 & .000 & Diterima \\
Profitabilitas & .003 & 2.373 & .018 & Diterima \\
Leverage & -.003 & -.401 & .689 & Ditolak \\
\hline
\end{tabular}

Sumber : Data Penelitian, 2019

Berdasarkan tabel 7 menunjukkan bahwa secara parsial variabel komite audit memiliki nilai $\mathrm{t}$ hitung sebesar $2.130>\mathrm{t}$ tabel dengan nilai signifikan sebesar 0,034 < 0,05 yang artinya komite audit berpengaruh positif signifikan terhadap CSRD. Sejalan dengan agency theory dimana dengan adanya Komite Audit dapat memberikan dukungan terhadap manajemen dalam hal memutuskan terkait dengan pengungkapan informasi lingkungan dan sosial dan mengurangi adanya asimetri informasi anatara pemilik dan manajemen, karena jika jumlah komite audit dirasa cukup untuk mengevaluasi semua kinerja perusahaan maka kinerja pengawasan pun akan lebih baik. Hasil penelitianini sejalan dengan temuan dari (Nyoman et al., 2018),(Fadhilla, 2017),(Erwanti, 2017) dan (Sayidah, 2017)menemukan komite audit berpengaruh terhadap CSRD.

Profitabilitas memiliki nilai $t$ hitung sebesar $2.373>2.251462243$ ( $\mathrm{t}$ tabel) dengan nilai signifikan sebesar 0,018 < 0,05 yang artinya profitablitias berpengaruh positif signifikan terhadap CSRD. Sejalan dengan stakeholders theory dimana dengan tingginya tingkat profitabilitas maka membuktikan bahwa adanya pemenuhan kepentingan kepada para stakeholders. Perusahaan dengan laba tinggi akan termotivasi untuk mengungkapkan informasi social lingkungannya. Hal ini karena Perusahaan mempunyai sumberdaya yang memadai dalam melakukan aktivitas CSR dan tidak hanya untuk mengejar profit saja namun Perusahaan memiliki kesadaran akan lingkungan sekitar tempat beroperasi. Hasil penelitianini sejalan dengan temuan dari (Oktavianawati \& Sri, 2018), (Abdullahi \& Ali, 2018), (Rohmah, 2015), (Laksmitaningrum \& Purwanto, 2013), (Badjuri, 2011),(Roitto, 2013), (Lucyanda \& Siagian, 2012)menemukan bahwa profitabilitas berpengaruh CSRD.

Ukuran perusahaan memiliki nilai t-hitung 5,044 $>2,251462243$ ( $\mathrm{t}$ tabel) dengan nilai signifikan sebesar $0,000<0,05$ yang artinya Ukuran perusahaan berpengaruh positif signifikan terhadap CSRD. Sejalan dengan agency theory bahwa adanya kontrak antara agen dan principal dimana dengan ukuran perusahaan yang besar dapat menambah kepercayaan dari phak investor. Semakin besar ukuran suatu perusahaan maka akan termotivasi dalam pengungkapan informasi social lingkungannya. Hal ini disebabkan karena perusahaan besar lebih dikenal di masyarakat dan dampak yang ditimbulkan akibat aktivitas perusahaan akan lebih besar pula. Hasil penelitianini sejalan dengan temuan dari (Abdullahi \& Ali, 2018),(Oktavianawati \& Sri, 2018), (Waluyo, 2017), Ilene (2016), (Dijk, 2015), (Trencansky et al., 2014),(Lucyanda \& Siagian, 2012)) menemukan bahwa ukuran perusahaan berpengaruh terhadap CSRD. 
Leverage memiliki t-hitung sebesar $-, 401<2,251462243$ ( $\mathrm{t}$ table) dengan signifikan sebesar 0,689 > 0,05 yang artinya leverage berpengaruh negative dan tidak signifikan terhadap CSRD. Sejalan dengan stakeholders theory bahwa Perusaahan dengan tingkat leverage lebih tinggi akan cenderung mengurangi kinerja social dan lingkungannya. Hal ini dilakukan agar tetap menjaga kepercayaan dari pihak stakeholders terutama kreditur, dimana dalam menjalankan operasinya perusahaanmemperoleh dana pinjamandari pihak eksternal. Sehingga perusahaan akan mengurangi pengeluaran biaya terkait dengan informasi yang dapat mengurangi laba perusahaan agar tidak menjadi perhatian dari pihak kreditur. Hasil penelitianini sejalan dengan temuan dari (Oktavianawati \& Sri, 2018), (Lucyanda \& Siagian, 2012) menemukan bahwa leverage berpengaruh secara negatif dan tidak signifikan terhadap CSRD.

\section{SIMPULAN}

Komite audit, Profitabilitas, Ukuran Perusahaan berpengaruh positif signifikan terhadap CSRD.Sedangkan Leverage berpengaruh negatif dan tidak signifikan terhadap CSRD. Namun secara simultan komite audit, profitabilitas, ukuran perusahaan dan leverage berpengaruh positif signifikan terhadap CSRD.

Penelitian ini masih memiliki keterbatasan yang dapat diperbaiki pada penelitian selanjutnya. Hasil dari penelitian menunjukan bahwa variabel leverage berpengaruh negatif tidak signifikan terhadap CSRD. Saran pada peneltiian selanjutnya perlu kajian mengenai leverage secara optimal kaitannya dengan CSRD karena secara teori berpengaruh karena perusahaan dengan rasio leverage yang tinggi akan mengungkapkan lebih banyak informasi. Dimana dengan leverage yang tinggi dapat menjadi kontrol bagi pihak manajemen.

Selain itu, variabel CSR masih diproksikan dengan menggunakan GRI G4.Saran penelitian selanjutnya perlu kajian lebih lanjut terkait variabel CSR dengan diproksikan menggunakan GRI Standars.

\section{REFERENSI}

Abdullahi, M. S., \& Ali, A. I. (2018). Determinants of Coporate Social Responsibility in Nigerian Cement Industry. 1(1), 164-178.

Badjuri, A. (2011). Corporate Governance Mechanism , Fundamental Factors , Corporate Social Responsibility ( Csr ) Disclosure Of A Natural Resource And Manufactur Company In Indonesian. Dinamika Keuangan Dan Perbankan, 3(1), 38-54.

Basuki, B., \& Patrioty, C. N. (2017). Pengaruh Regulasi Pemerintah, Tekanan Masyarakat, Tekanan Organisasi Lingkungan, Tekanan Media Massa, Terhadap Corporate Social Disclosure. EKUITAS (Jurnal Ekonomi Dan Keuangan), 15(1),

23. https:/ / doi.org/10.24034/j25485024.y2011.v15.i1.2271

Cahyaningtyas, F. (2018). Pengungkapan Corporate Social Responsibility (CSR) pada Lembaga Keuangan yang Terdaftar di BEI. Journal of Economics, Business, and Government Challenges, 1(1), 10-21. https://doi.org/10.33005/ebgc.v1i1.5

Da Silveira, L. M., \& Petrini, M. (2018). Sustainable Development and Corporate Social Responsibility: A bibliometric analysis of International Scientific 
Production. Gestao e Producao, 25(1), 56-67. https://doi.org/10.1590/0104-530X3173-16

Dijk, M. Van. (2015). The impact of CSR motives and firm size on CSR performance, and the influence of firm size on stakeholder-driven CSR motives . 6052193, 2014-2015.

Erwanti, Y. (2017). Pengaruh Ukuran Perusahaan, Profitabilitas, Dewan Komisaris, Komite Audit Dan Kualitas Audit Terhadap Pengungkapan Informasi Pertanggungjawaban. Pengaruh Ukuran Perusahaan, Profitabilitas, Dewan Komisaris, Komite Audit Dan Kualitas Audit Terhadap Pengungkapan Informasi Pertanggungjawaban, 6(4), 295-308.

Fadhilla, A. F. (2017). Relationship Analysis of Corporate Governance, Corporate Social Responsibility Disclosure and Economic Consequences: Empirical Study of Indonesia Capital Market. The South East Asian Journal of Management. 11(2), 164-183.

Freeman, R. E. (2004). The Stakeholder Approach Revisited. Zeitschrift Für Wirtschafts- Und Unternehmensethik, 5(3), 228-241. https:/ / doi.org/10.5771/1439-880x-2004-3-228

Ghozali, Imam. (2011). Aplkasi Analisis Multivariate dengan Program IBM SPSS19. Semarang:Badan Penerbit Universitas Diponegoro.

Hang, T. T. T., \& Ngoc, B. T. (2018). Effect of Corporate Social Responsibility Disclosure on Financial Performance. Asian Journal of Finance $\mathcal{E}$ Accounting, 10(1), 40. https:/ / doi.org/10.5296/ajfa.v10i1.12592

Ilene. (2016). Pengaruh Tipe Industri, Ukuran Perusahaan, Kepemilikan Asing, Regulasi Pemerintah, Metode Dan Gaya Komunikasi, Performance Tata Kelola Perusahaan Terhadap Luas Pengungkapan Corporate Social Responsibility. Media Riset Akuntansi, 6(2), 61-86.

Laksmitaningrum, C. F., \& Purwanto, A. (2013). Analisis Pengaruh Karakteristik Perusahaan, Ukuran Dewan Komisaris Dan Struktur Kepemilikan Terhadap Pengungkapan Csr (Studi Empiris pada Perusahaan Manufaktur yang Terdaftar di Bursa Efek Indonesia Tahun 2009-2011). 2, 248-257.

Lucyanda, J., \& Siagian, L. G. (2012). The Influence of Company Characteristics Toward Corporate Social Responsibility Disclosure. The 2012 International Conference on Business and Management, Viii, 601-619.

Mardikanto, T. (2014).Tanggungjawab Sosial Korporasi. Bandung: Alfabeta.

Nyoman, N., Jayantini, M., \& Sujana, I. K. (2018). Intervention of Sustainability Report Disclosure toward the Effect of Good Corporate Governance on Financial Performance. 4531, 111-123.

Oktavianawati, L., \& Sri, I. F. (2018). The Factors that Influence the Disclosure of Corporate Social Responsibility (CSR). AAJ: Accounting Analysis Journal, 7(2), 119-126. https:/ / doi.org/10.15294/aaj.v7i2.23738

Pemerintah Indonesia. (2012). Peraturan Pemerintah tentang Tanggung Jawab Sosial dan Lingkungan (TJSL) Perseroan Terbatas. Lembaran RI Tahun 2012. Jakarta : Sekretariat Negara.

Pemerintah Indonesia.(2007). Undang-undang Nomor 40 Tahun 2007 tentang Perseroan Terbatas. Lembaran RI Tahun 2007. Jakarta:Sekretariat Negara 
Respati, R. D., \& Hadiprajitno, P. B. (2015). Perusahaan, Tipe Industri , Dan Pengungkapan Media Terhadap Pengungkapan Corporate Social Responsibility. Diponegoro Journal of Accounting, 4, 1-11.

Rohmah, D. (2015). Vol. 5, No. 2, Oktober 2015 E S E N S I Jurnal Bisnis dan Manajemen. 5(2), 243-262.

Roitto, A. (2013). Factors Effecting Corporate Social Responsibiity Disclosure Ratings: an Empirical Study of Finnish Listed Companies. Oulu Business School, April.

Sartono, R,A. (2012). Manajemen Keuangan Teori dan Aplikasi. Edisi Yogyakarta: BPFE-Yogyakarta.

Sayidah, N. (2017). Faktor-Faktor Yang Mempengaruhi Pengungkapan Corporate Social Responsibility. Jurnal Analisa Akuntansi Dan Perpajakan, 1(2), 6379. https://doi.org/10.25139/jaap.v1i2.144

Trencansky, D., Tsaparlidis, D., \& Ittonen, K. (2014). The Effects of Company's Age, Size and Type of Industry on the Level of CSR. Umea School of Business and Economics, 1-81. http://www.divaportal.org/smash/get/diva2:757602/FULLTEXT01.pdf

Triyono, \& Achyani, F. (2016). Determinan Dan Peran Kualitas Corporate Governance Dalam Hubungan Antara Struktur Kepemilikan Dan Karakteristik Perusahaan Dengan Kinerja Perusahaan. The 3rd University Research Colloquium, 119-136.

Waluyo, W. (2017). Firm size, firm age, and firm growth on corporate social responsibility in Indonesia: The case of real estate companies. European Research Studies Journal, 20(4), 360-369.

Widyadmono, V. M. (2014). The impact of type of industry, company size and leverage on the disclosure of corporate social responsibility: Case on Companies listed in Indonesia Stock Exchange 2009-2012. Jurnal Siasat Bisnis, 18(1), 118-132. https:/ / doi.org/10.20885/jsb.vol18.iss1.art9

Yusuf, Y. Y. (2017). Determinan Pengungkapan Csr Dan Pengaruhnya Terhadap Nilai Perusahaan. Jurnal Bisnis Dan Manajemen, 4(2), 197-216. https://doi.org/10.26905/jbm.v4i2.1701 